\title{
16
}

\section{SUSTAINABLE WAYS TO MANAGE WASTE IN HEALTHCARE FACILITIES}

\author{
Ananya Tewari and Shyamala Mani
}

\section{Introduction}

The healthcare sector plays a vital role in protecting the health of individuals. However, it contributes to the climate crisis through its energy-intensive operations, manufacturing of various healthcare products, transportation and waste management. The World Bank has estimated GHG emissions for the Indian healthcare sector to be between 8 million and 14 million metric tonnes of carbon dioxide equivalent $\left(\mathrm{mtCO}_{2} \mathrm{e}\right)$. A 2020 study suggests that according to the emission reduction experience of some developed countries, waste is the second-largest research area for emission reduction after energy (Xin et al., 2020).

The health sector significantly contributes to the total waste load of a country. It generates large quantities of infectious, non-infectious, general and hazardous chemical waste. An enormous amount of energy is spent in treatment and disposal of this waste. This chapter looks at:

1. Practices in waste management and disposal, including future sustainable strategies, that will help to reduce greenhouse gas emissions and increase the potential for climate change mitigation from healthcare establishments.

2. The management of biomedical waste originating from healthcare facilities, including the characterisation, quantification, segregation, storage, transport, treatment and disposal of biomedical waste.

3. Climate-smart and clean waste disposal mechanisms that will not only promote the development and supply of sustainable products but will also prepare the health sector for climate-related health hazards.

\section{Waste management and disposal}

Every department within a healthcare facility generates waste. These can be broadly divided into three categories: healthcare waste, general waste and other waste. Healthcare waste mostly includes infectious waste, chemicals, expired pharmaceuticals and sharps. General waste consists of discarded 


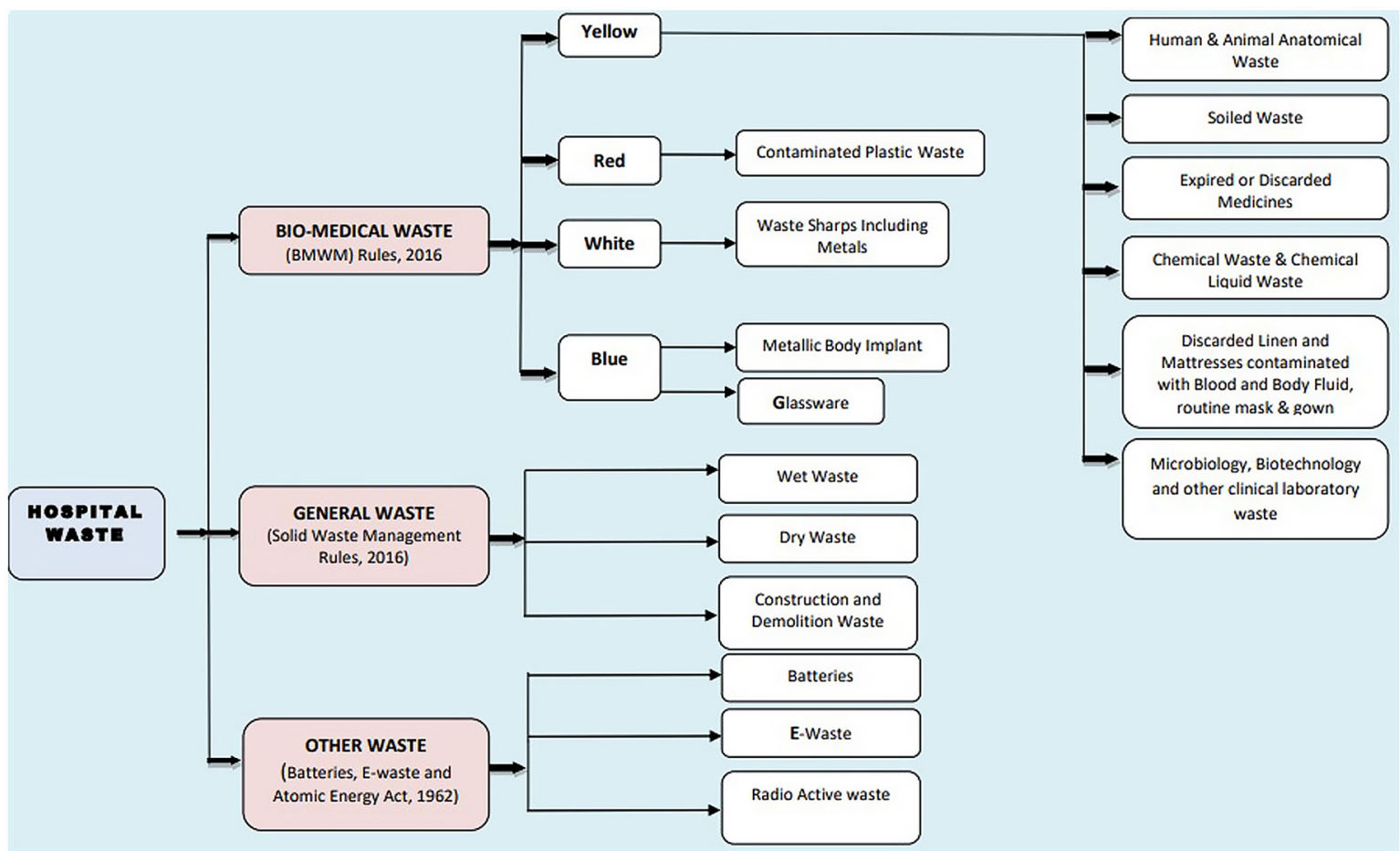

Figure 16.1 Different categories and classification of waste generated from healthcare facilities. Note: According to the Solid Waste Management Rules, 2016 "Domestic Hazardous Waste" is a separate category under the "General Waste" that includes sanitary waste. However, this waste is collected as part of dry waste under the general waste category.

Source: Ministry of Health, Family and Welfare and Central Pollution Control Board. 
packaging of medical items, food waste and waste from offices (Aljabre, 2002). Other wastes include e-waste, hazardous waste, plastic waste, etc.

Various regulations are in place to manage each waste category. Hospitals fall under the category of Bulk Waste Generator i.e. an establishment that generates more than $100 \mathrm{~kg}$ of waste per day (of all waste streams put together) (BSWGC, 2016). Therefore, specifications prescribed in listed regulations are applicable to healthcare facilities for managing and segregating each of their waste categories. Solid waste generated from hospitals consists of bandages, linen and other infectious waste (30-35\%), plastics $(7-10 \%)$, disposable syringes $(0.3-0.5 \%)$, glass $(3-5 \%)$ and other general wastes including food (40-45\%) (Patil \& Shekdar, 2001). Given the nature and risks associated with biomedical waste, its management requires increased attention and diligence in order to avoid adverse health outcomes associated with exposure to infectious agents and toxic substances. Healthcare waste, also referred to as biomedical waste (BMW) in this chapter, is any waste produced during the diagnosis, treatment or immunisation of humans or related animal research activities or in the production or testing of biologicals or in health camps (Biomedical Waste Management Rules, 2016) (Figure 16.1 and Table 16.1).

Table 16.1 Policy framework for managing various types of waste generated in India

\begin{tabular}{|c|c|c|c|c|}
\hline $\begin{array}{l}\text { S. } \\
\text { No. }\end{array}$ & $\begin{array}{l}\text { Different } \\
\text { Waste }\end{array}$ & Regulations & $\begin{array}{l}\text { Concerned } \\
\text { Authorities }\end{array}$ & Stakebolders \\
\hline 1. & Solid Waste & $\begin{array}{l}\text { Solid Waste } \\
\text { Management } \\
\text { Rules, } 2016\end{array}$ & $\begin{array}{l}\text { Ministry of } \\
\text { Environment, } \\
\text { Forests and } \\
\text { Climate } \\
\text { Change, and } \\
\text { Ministry of } \\
\text { Housing and } \\
\text { Urban Affairs }\end{array}$ & $\begin{array}{l}\text { Municipal areas, urban } \\
\text { agglomerations, } \\
\text { census towns, notified } \\
\text { industrial townships, } \\
\text { Indian Railways, } \\
\text { airports, special } \\
\text { economic zones, } \\
\text { religious and historical } \\
\text { places, State and } \\
\text { Central Government } \\
\text { organizations }\end{array}$ \\
\hline 2. & $\begin{array}{l}\text { Plastic } \\
\text { Waste }\end{array}$ & $\begin{array}{l}\text { The Plastic } \\
\text { Waste } \\
\text { (Management } \\
\text { and Handling) } \\
\text { Rules, 2016 }\end{array}$ & $\begin{array}{l}\text { Ministry of } \\
\text { Environment, } \\
\text { Forests and } \\
\text { Climate } \\
\text { Change, and } \\
\text { Ministry of } \\
\text { Housing and } \\
\text { Urban Affairs }\end{array}$ & $\begin{array}{l}\text { Manufacturers of plastic } \\
\text { items, packaging } \\
\text { industry, food and } \\
\text { catering services, } \\
\text { FMCG industries, } \\
\text { event organisers, } \\
\text { households, urban } \\
\text { shopping areas, } \\
\text { offices, automobile } \\
\text { industries and } \\
\text { manufacturers of } \\
\text { electronic items. }\end{array}$ \\
\hline
\end{tabular}

(Continued) 
Table 16.1 (Continued)

\begin{tabular}{|c|c|c|c|c|}
\hline $\begin{array}{l}S . \\
\text { No. }\end{array}$ & $\begin{array}{l}\text { Different } \\
\text { Waste }\end{array}$ & Regulations & $\begin{array}{l}\text { Concerned } \\
\text { Authorities }\end{array}$ & Stakeholders \\
\hline 3. & $\begin{array}{l}\text { Biomedical } \\
\text { Waste }\end{array}$ & $\begin{array}{l}\text { Biomedical } \\
\text { Waste } \\
\text { Management } \\
\text { Rules, } 2016\end{array}$ & $\begin{array}{l}\text { Ministry of } \\
\text { Environment, } \\
\text { Forests and } \\
\text { Climate } \\
\text { Change }\end{array}$ & $\begin{array}{l}\text { Healthcare } \\
\text { establishments, } \\
\text { CBWTF and TSDF }\end{array}$ \\
\hline 4. & $\begin{array}{l}\text { Hazardous } \\
\text { Waste }\end{array}$ & $\begin{array}{l}\text { Hazardous } \\
\text { Waste } \\
\text { Management } \\
\text { Rules, } 2016\end{array}$ & $\begin{array}{l}\text { Ministry of } \\
\text { Environment, } \\
\text { Forests and } \\
\text { Climate } \\
\text { Change }\end{array}$ & $\begin{array}{l}\text { TSDF, petrochemicals, } \\
\text { pharmaceuticals, } \\
\text { chemicals, fertilisers } \\
\text { and general } \\
\text { engineering industries }\end{array}$ \\
\hline 5. & E- Waste & $\begin{array}{l}\text { E-waste } \\
\text { (Management) } \\
\text { Rules, } 2016\end{array}$ & $\begin{array}{l}\text { Ministry of } \\
\text { Environment, } \\
\text { Forests and } \\
\text { Climate } \\
\text { Change }\end{array}$ & $\begin{array}{l}\text { Equipment } \\
\text { manufacturers and } \\
\text { end users }\end{array}$ \\
\hline
\end{tabular}

Source: Created by CCDC-PHFI

\section{Waste management in the Indian health sector: process flow}

India generates 614 tonnes of biomedical waste on a daily basis (BMWM Annural Report 2018). It is estimated to reach 775.5 tonnes by 2022, says a study conducted by ASSOCHAM and Velocity. Management of biomedical waste originating from healthcare facilities follows the cradle-to-grave approach which includes characterisation, quantification, segregation, storage, transport, treatment and disposal of biomedical waste (Datta et al., 2018). Healthcare facilities are required to segregate their biomedical waste into four colour-coded categories - yellow, red, white and blue - at its point of segregation, before handing it over to the common biomedical waste treatment and disposal facility (CBWTF) operators to avoid environmental and occupational health risks (Table 16.2).

All the four waste categories are collected by the authorised collector or CBWTF operator for final treatment and disposal. The purpose of treatment is to reduce the potential hazards posed by the biomedical waste (WHO, 2014). The choice of a waste treatment system involves consideration of waste characteristics, technology capabilities, requirements, environmental and safety factors and costs (WHO, 2014). Hazardous components of biomedical waste particularly sharps, infectious and pathological waste are treated by thermal, chemical, irradiation, biological and mechanical processes (WHO, 2014). The diagram below describes the process flow of biomedical waste management (Figure 16.2).

Waste in Yellow bags is the only category that needs to be incinerated, after which the ash is disposed of at a Treatment, Storage and Disposal Facility (TSDF). Some of the yellow category wastes such as used blood 
Table 16.2 Colour-coded BMW categories along with their treatment and disposal methods

\begin{tabular}{|c|c|c|c|}
\hline Category & Type of Bag/Container Used & Type of Waste & Treatment/Disposal Option \\
\hline Yellow & $\begin{array}{l}\text { Non- chlorinated plastic bags } \\
\text { Separate collection system leading to } \\
\text { an effluent treatment system for } \\
\text { chemical liquid waste }\end{array}$ & $\begin{array}{l}\text { - Human anatomical waste } \\
\text { - Animal anatomical waste } \\
\text { - Soiled Waste } \\
\text { - Expired of discarded medicines } \\
\text { - Chemical waste } \\
\text { - Microbiological, biotechnological } \\
\text { - Chd other clinical lab waste } \\
\text { - Chemical liquid waste }\end{array}$ & $\begin{array}{l}\text { Incineration or plasma pyrolysis or } \\
\text { deep burial }\end{array}$ \\
\hline Red & $\begin{array}{l}\text { Non- chlorinated plastic bags or } \\
\text { containers }\end{array}$ & $\begin{array}{l}\text { Contaminated waste (Recyclable) } \\
\text { tubing, bottles, intravenous tubes } \\
\text { and sets, catheters, urine bags, } \\
\text { syringes (without needles) and } \\
\text { gloves }\end{array}$ & $\begin{array}{l}\text { Autoclaving/Microwaving/ } \\
\text { Hydroclaving and then sent for } \\
\text { recycling. Not be sent to landfill. }\end{array}$ \\
\hline White & $\begin{array}{l}\text { Puncture, leak and tamper proof } \\
\text { containers }\end{array}$ & Waste sharps including metals & $\begin{array}{l}\text { Autoclaving or dry heat sterilisation } \\
\text { followed by shredding or mutilation } \\
\text { or encapsulation }\end{array}$ \\
\hline Blue & $\begin{array}{l}\text { Puncture proof and leak proof boxes } \\
\text { or containers with blue coloured } \\
\text { marking }\end{array}$ & Glassware & $\begin{array}{l}\text { Disinfection/autoclaving/microwaving/ } \\
\text { hydroclaving and then sent for } \\
\text { recycling }\end{array}$ \\
\hline
\end{tabular}




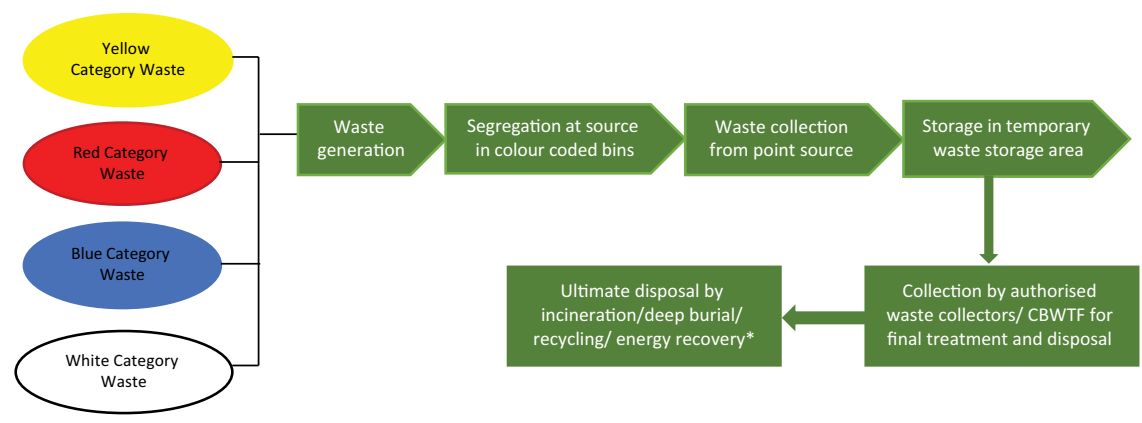

Figure 16.2 Methods prescribed in the BMWM rules for different waste categories.

Source: CCDC-PHFI

bags, vacutainers and other microbiological waste are to be pre-treated by autoclaving at the Health Care Facility (HCF) level before handing over to Captive Biomedical Waste Treatment Facilities (CBWTFs). All other waste is to be treated and disposed at CTFs or Captive Treatment Facilities only (in case of non-availability of CBWTFs).

\section{Why is waste segregation important?}

Segregation at source and waste reduction is the basic principle of biomedical waste management (BMWM) (Datta et al., 2018). It is the first and most essential step in BMWM (Sengodan, 2014). Segregation of each category at its source not only decreases the waste volume of each waste stream and its ease of processing and disposal (and consequently, the burden on waste management systems), but also prevents occupational health risks to the sanitation and waste-handling sector. Waste segregation is an effective procedure for reducing risks associated with and minimising the cost of waste disposal (Khobragade, 2019). Waste segregation can help in ensuring that incinerators are not overwhelmed with unwanted waste items.

According to the United Nations Environment Programme (UNEP), about $25 \%$ of biomedical waste is hazardous in nature. Part of this waste requires special treatment. The cost of its treatment and disposal can be greatly reduced if it is appropriately segregated (WHO Data Sheet). The remaining $75 \%$ of waste is of a non-hazardous nature that is generated from offices, kitchen and housekeeping areas. If the non-hazardous waste is mixed with potentially infectious and hazardous waste, it can lead to an increased volume of hazardous waste. In order to achieve adequate segregation, clear protocols for identifying different waste categories and separate disposal methods are essential. 


\section{Challenges on the ground}

The Indian policy for the management of biomedical waste has been in place since 1998. The regulations of 1998 were later modified in the years 2000, 2003 and 2011. In 2016, new rules for BMWM were notified by the Ministry of Environment, Forests and Climate Change (MoEFCC) and these were subsequently amended in 2018 and 2019. In spite of all the amendments that were intended to address practical constraints, several studies suggest inadequate enforcement of BMWM regulations. As early as 2001, i.e. after the first amendment made to the 1998 rules, a study conducted by the Centre for Environment Education indicated discrepancies in the implementation of rules (Verma et al., 2008). In 2008, another study revealed inadequacies across Delhi nursing homes and smaller hospital establishments in waste segregation, storage and disposal. The study highlighted the malpractice of collecting sharps waste in plastic bags instead of puncture-proof containers, lack of dedicated space for waste storage and the practice of handing over laboratory waste to the external service provider without disinfecting the waste (Verma et al., 2008).

Later in 2016, a report by the Comptroller and Auditor General (CAG) of India highlighted the gaps in waste segregation across different facilities in Mumbai and Nashik. Some of the evaluated facilities were found to have used plastic bags instead of puncture-proof containers for glass and metal sharps waste. In Mumbai, the CAG found two facilities to have mixed sharp wastes with incinerable waste and some BMW was also found to be stored near a patient's bed (Kakodkar, 2017). As per the Central Pollution Control Board's Annual Report on Biomedical Waste Management of 2018, out of the total 2,70,416 healthcare facilities (HCFs) in India, 27,301 ( $10 \%)$ violated the biomedical waste management rules. About 16,956 showcause notices/directions were issued to defaulter HCFs. A total of 12,326 HCFs have captive treatment facilities for BMW treatment and disposal (BMWM Annual Report, 2018).

Another CAG report of 2018 that evaluated the performance audit of Solid Waste Management in Karnataka stated that healthcare institutions were functioning without authorisation and the facilities had resorted to unauthorised disposal of biomedical waste (CAG, Govt. of India, 2018). A recent study conducted by Toxics Link in 2019 across HCFs of Delhi showed that practices in larger establishments were more or less compliant with the new rules, but that smaller establishments were found to be lacking in several aspects such as absence of ETP/STPs, lack of personal protective equipment, waste storage in the open, manual waste transportation within the facilities, improper waste quantum records and lack of accident reporting (Mahesh and Syed, 2019). 


\section{Environmental concerns}

Yellow category waste has eight sub-categories that cumulatively contribute to a large proportion of the total biomedical waste generated from HCFs. Due to its infectious and hazardous nature, most of this waste is subject to high heat thermal processes such as incineration. If not incinerated, many of the waste items can end up in regular landfill sites or garbage dumps (Fullerton, 2017). Incineration is a high-temperature, dry oxidation process that reduces organic and combustible waste to inorganic, incombustible matter and theoretically results in a significant reduction of waste volume and weight (WHO, 2014). Even though incineration is considered to be the most preferred method to dispose of yellow category waste as it can efficiently kill pathogens while reducing the volume of waste, there are several environmental concerns associated with the process.

Incineration is highly dependent on the use of fossil fuel, adding to the issues of climate change along with increasing particulate matter (PM) pollution. Many respiratory diseases are closely associated with increased levels of $\mathrm{PM}_{10}$ and $\mathrm{PM}_{2.5}$, and the increase in PM is known to exacerbate such conditions. Further, the incineration of biomedical waste releases combustion by-products into the atmosphere and generates residual ash which can contain heavy metals, requiring disposal in hazardous waste treatment facilities. The combustion produces gaseous emissions such as steam, carbon dioxide, nitrogen oxides, a range of volatile substances (e.g. metal compounds, halogenic acids, products of incomplete combustion), particulate matter and solid residues in form of ashes (WHO, 2014). These gaseous emissions are directly released into the atmosphere and contribute to the greenhouse effect. In waste incineration plants, $\mathrm{CO}_{2}$ constitutes the chief climate-relevant emission that is considerably higher than other climaterelevant emissions (Johnke et al., 2003). The climate-relevant $\mathrm{CO}_{2}$ emissions from waste incineration are determined by the proportion of waste whose carbon compounds are assumed to be of fossil origin (Johnke et al., 2003). The level of fossil $\mathrm{CO}_{2}$ emitted by burning 1 tonne of waste depends on what is burned (Zero Waste Europe, 2019).

According to the Stockholm Convention: "If medical waste is incinerated in conditions that do not constitute best available techniques or best environmental practices, there is potential for the release of polychlorinated dibenzodioxins and polychlorinated dibenzofurans in relatively high concentrations" (Secretariat of the Stockholm Convention, 2006). Dioxins are considered to have cancer-causing potential and are human carcinogens as per the International Agency for Research on Cancer, an arm of WHO (Gautam et al., 2010).

In order to prevent environmental damage, current regulations for BMWM have standards for incineration along with other treatment technologies 
such as microwaving and autoclaving. However, segregation at source and volume reduction of biomedical waste fractions can reduce disposal costs, the amount of raw materials required for the process, and energy use. A reduction in GHG emissions from waste disposal methods and waste volume can also be achieved through better purchasing, minimising the packaging, opting for recycling and composting or biodigestion of non-healthcare biodegradable waste $(\mathrm{HCWH}, 2020)$. Reducing the distance of waste transportation for treatment and disposal can also contribute to a decrease in GHG emissions (HCWH, 2020). This can be done by operationalising adequate numbers of CBWTFs in all regions of the country, which currently is the biggest challenge in the area of BMWM. Currently, there are only 200 CBWTFs that are operational and an additional 28 are under construction (BMWM Annual Report, 2018). Furthermore, there are seven states where there are no CBWTFs.

\section{Climate-smart waste practices for the Indian healthcare sector}

Best practices for managing healthcare waste are primarily based on the appropriate segregation of waste at source based on its hazardousness, infectiousness and the type of material of the waste. Segregation is most effective when done at the waste generation source (Khobragade, 2019). For instance, segregation of uninfected and infectious waste is a must as this is a major factor determining the facilities and energy requirements during the entire process of waste collection, storage and its treatment and disposal. The Solid Waste Management Rules (2016) have provisions for colour coding different categories of waste such as green for biodegradable food waste with the recycling symbol, light blue for non-biodegradable (non-infected) general waste with the recycling symbol, black for the collection of domestic hazardous waste such as residual paints, pesticides, CFLs, tube lights, batteries and disinfectant containers, etc. Similarly, as per the BMWM Rules (2016), BMW is to be segregated into four colour-coded categories that have been discussed in the previous sections.

Once these categories are colour coded and segregated, it is easy to assign sustainable technologies without having to incinerate the entire amount of waste in case of mixing. For instance, the biodegradable waste category, especially food waste, can be processed by biomethanation and composting. Red category waste can be autoclaved, blue category waste can either be chemically disinfected or autoclaved or microwaved, and white category waste can be treated by dry heat sterilisation and steam sterilisation. All three categories, namely red, blue and white, can then be given to authorised recyclers for recycling and manufacture of different materials after the treatment (but not used for food or medical purposes). Recyclable wastes can be recycled, domestic hazardous chemical waste can be neutralised and treated and disposed in TSDF. If this is successfully achieved, only $25-30 \%$, that is, the biomedical waste (yellow category) would be the only category 
requiring incineration. This can greatly reduce the volume of incinerable waste and improve the performance efficiency of incinerators.

\section{Benefits of biomethanation and composting}

Adoption of biomethanation or composting for onsite treatment of biodegradable waste can be sustainable ways to treat biodegradable waste (Anand, 2019). The benefits of biomethanation composting of the biodegradable fraction of cooked and uncooked food waste are that these processes speed up the degradation. Another advantage of biomethanation is that even possibly infected food waste is processed in a covered predigester (for stabilising $\mathrm{pH}$ ) or in the main digester, and is exposed to a retention time between 15 to 21 days at a steady temperature of $35-40^{\circ} \mathrm{C}$. The process develops conditions that could be sufficient to kill pathogenic bacteria and viruses. The process of biomethanation produces biogas, which is a combination of methane, carbon dioxide, hydrogen sulphide, etc., with efficient biodigesters producing at least $70-72 \%$ methane. This biogas has been tested as a clean fuel for cooking, heating and other purposes. Biogas is most easily produced from gobar gas digesters and food waste digesters.

Direct composting of kitchen waste, food leftovers and soft garden waste under aerobic conditions in pits, piles or in-vessel composters shows that

\section{Box 16.1 Case study}

\section{Composting for the on-site treatment of biodegradable waste in the Indian healthcare sector}

There are several case studies in India where food waste from healthcare establishments is being composted either in in-vessel composters or the traditional pits of appropriate capacities. Lokmanya Tilak Municipal General Hospital, commonly known as "Sion Hospital," a public sector hospital situated in Mumbai has adopted on-site treatment of their food waste through aerobic bacterial composting. Thirteen brick-walled compost pits measuring $9 \mathrm{ft}$. long, $4.5 \mathrm{ft}$. wide and $3.5 \mathrm{ft}$. high have been constructed for the treatment of wet food waste in the hospital campus. The manure generated after this treatment is collected and used in the campus plantations maintained at the hospital. A similar initiative has been taken up by HBT Medical College and Dr. R. N. Cooper Hospital, a municipal general hospital in Mumbai. The hospital management has taken up vermi-composting to treat their food waste and soft garden waste.

Source: HELP Case Studies, 2018 
temperatures inside the composting piles reach $55-65^{\circ} \mathrm{C}$. When the waste, along with bulk matter such as garden waste, moisture and inoculum, remains inside the pile for nearly seven days between turnings, these temperatures are sufficient to kill pathogenic microorganisms, including the SARS-CoV-2 virus. It also helps in decomposition and mineralisation of food waste into compost and humus, which are necessary ingredients for the growth of plants, trees, etc. (Box 16.1).

\section{Key takeaways}

- Biomedical waste is hazardous but all the other types of waste generated in healthcare establishments are not necessarily infectious or hazardous.

- Non-compliance with segregation, storage and treatment policies and subjecting the entire waste from healthcare establishments to incineration is highly unsustainable.

- Practices as outlined above would help in reducing greenhouse gases and increase the climate change mitigation potential of a healthcare establishment and make it climate resilient.

- Mobilising the health systems towards adopting such practices for safe handling and disposal of healthcare waste are essential in order to bring overall health, economic and environmental benefits.

\section{References}

Aljabre, S. H. M. (2002). Hospital generated waste: A plan for its proper management. Journal of Family \& Community Medicine, 9(2), 61-65. https://www.ncbi. nlm.nih.gov/pmc/articles/PMC3430187/\#: :text=Hospitals\%20are\%20important $\% 20$ sites $\% 20$ for $\% 20$ the $\% 20$ generation $\% 20$ of $\% 20$ waste., and $\% 20$ radioactive $\% 20$ items $\% 20$ and $\% 20$ sharps.

Anand, Kisslay (2019). Solid waste management initiatives in Urban India: A Compendium. Ministry of Housing and Urban Affairs, National Institute of Urban Affairs. 88-90. NIUA. https://niua.org/intranet/sites/default/files/745.pdf.

BMWM Annual Report. (2018). Annual report on biomedical waste management as per biomedical waste management rules, 2016 for the year 2018. CPCB: https://cpcb.nic.in/uploads/Projects/Bio-Medical-Waste/AR_BMWM_2018.pdf

CAG, Govt. of India. (2018). Performance audit of solid waste management in urban local bodies, Government of Karnataka. Comptroller and Auditor General of India. https://cag.gov.in/sites/default/files/audit_report_files/Report_No_4_ of_2018_Performance_Audit_of_Solid_Waste_Management_in_Urban_Local_ Bodies_Government_of_Karnataka.pdf

Datta, P., Mohi, G., \& Chander, J. (2018). Biomedical waste management in India: Critical appraisal. Journal of Laboratory Physicians, 10(1), 6-14. https://www. ncbi.nlm.nih.gov/pmc/articles/PMC5784295/

Fullerton, K. (2017). The Environmental Hazards of Medical Waste. Sense and Sustainability. https://www.senseandsustainability.net/2017/09/29/dumpedmedical-waste-hazardous-to-the-environment/ 
Gautam, V., Thapar, R., \& Sharma, M. (2010). Biomedical waste management: Incineration vs. environmental safety. Indian Journal of Medical Microbiology, 28(3), 191-192. doi: 10.4103/0255-0857.66465.

HELP. (2018). HELP case studies: On site food waste management to reduce the waste load on municipal dump site. Health and Environment Leadership Platform (HELP) https://www.ceh.org.in/wp-content/uploads/2018/10/CaseStudy_Waste_Sion.pdf

Health Care Without Harm. (2020). Healthcare waste: Our vision. HCWH. https://noharm-global.org/issues/global/our-vision.

Johnke, B., Robert, H., Eugene, L., Bill, I., Martinsen, T., \& Mareckova, K. (2003). Emissions from waste incineration. Good practice guidance and uncertainty management in national greenhouse gas inventories. https://www.ipcc-nggip.iges. or.jp/public/gp/bgp/5_3_Waste_Incineration.pdf

Kakodkar, P. (2017). Inadequate management of bio-medical waste in Maharastra: CAG. The Times of India, 17, 52. https://timesofindia.indiatimes.com/city/mumbai/inadequate-management-of-bio-medical-waste-in-maharashtra-cag/articleshow/60209901.cms

Khobragade, S. D. (2019). Health care waste: Avoiding hazards to living and non living environment by efficient management. Fortune Journal of Health Sciences, $2(2), \quad 014-029$. http://www.fortunejournals.com/articles/health-care-wasteavoiding-hazards-to-living-and-non-livingnbspenvironment-by-efficientmanagementp.pdf

Mahesh, P. B., \& Syed, S. (2019). Spreading infection? Healthcare facilities in Delhi. Toxics Link. http://toxicslink.org/docs/Spreading\%20infection.pdf

Ministry of Housing and Urban Affairs, Govt. of India. (2017). Bulk solid waste generators: A step by step guidance for urban local bodies to implement the solid waste management rules, 2016. MoHUA. http://164.100.228.143:8080/sbm/content/writereaddata/Bulk\%20Waste\%20Generator\%20Book.pdf

Patil, A. D., \& Shekdar, A. V. (2001). Health-care waste management in India. Journal of Environmental Management, 63, 211-220. doi:10.1006/ jema.2001.0453.

Sengodan, V. C. (2014). Segregation of biomedical waste in an South Indian tertiary care hospital. Journal of Natural Science, Biology and Medicine, 5(2), 378-382. doi: 10.4103/0976-9668.136194

SSC - Secretariat of the Stockholm Convention. (2006). Revised draft guidelines on best available techniques and provisional guidance on best environmental practices relevant to Article 5 and Annex $C$ of the Stockholm Convention on Persistent Organic Pollutants. Secretariat of the Stockholm Convention.

UNEP and WHO. (2014). National health-care waste management plan, guidance manual. WHO. https://www.who.int/water_sanitation_health/medicalwaste/en/ guidancemanual1.pdf

Verma, L. K., Mani, S., Sinha, N., \& Rana, S. (2008). Biomedical waste management in nursing homes and smaller hospitals in Delhi. Waste Management, 28(12), 2723-2734. doi: 10.1016/j.wasman.2007.12.013

WHO. (2014). Safe Management of Wastes from Healthcare Activities (2nd Ed.). https://www.who.int/water_sanitation_health/publications/2011/ 9789241548151_ch10.pdf 
Xin, C., Tingting, Z., Sang-Bing, T., Yu-Ming, Z., \& Jiangtao, W. (2020). An empirical study on greenhouse gas emission calculations under different municipal solid waste management strategies. Applied Science, 2020(10), 1673. doi: 10.1016/j. wasman.2007.12.013

Zero Waste Europe. (2019). The impact of waste-to-energy incineration on climate, 2019. https://zerowasteeurope.eu/wp-content/uploads/edd/2019/09/ZWE_Policybriefing_The-impact-of-Waste-to-Energy-incineration-on-Climate.pdf 